Article

\title{
Over-Winter Survival and Nest Site Selection of the West-European Hedgehog (Erinaceus europaeus) in Arable Dominated Landscapes
}

\author{
Lucy E. Bearman-Brown ${ }^{1, * \mathbb{C}}$, Philip J. Baker ${ }^{2}$, Dawn Scott ${ }^{3}$, Antonio Uzal ${ }^{4}{ }^{\mathbb{D}}$, Luke Evans ${ }^{2}$ \\ and Richard W. Yarnell ${ }^{4}$ \\ 1 Department of Animal \& Agriculture, Hartpury University, Gloucestershire GL19 3BE, UK \\ 2 School of Biological Sciences, University of Reading, Reading RG6 6AH, UK; p.j.baker@reading.ac.uk (P.J.B.); \\ L.C.Evans@pgr.reading.ac.uk (L.E.) \\ 3 School of Life Sciences, Keele University, Staffordshire ST5 5BG, UK; d.scott@keele.ac.uk \\ 4 School of Animal, Rural \& Environmental Sciences, Nottingham Trent University, Southwell, \\ Nottinghamshire NG25 0QF, UK; antonio.uzal@ntu.ac.uk (A.U.); richard.yarnell@ntu.ac.uk (R.W.Y.) \\ * Correspondence: lucy.bearman-brown@hartpury.ac.uk; Tel.: +44-1452-702465
}

Received: 22 July 2020; Accepted: 13 August 2020; Published: 19 August 2020

Simple Summary: Hedgehogs (Erinaceus europaeus) have declined markedly in the UK in recent decades. One key stage that could affect their population dynamics is the annual winter hibernation period. Therefore, we studied two contrasting populations in England to examine patterns of winter nest use, body mass changes and survival during hibernation. On average, animals at both sites weighed the same prior to, and used the same number of nests, during hibernation. There was a marked difference in survival rates between the two sites, but no animals died during hibernation; all deaths occurred prior to or after the hibernation period, mainly from predation or vehicle collisions. Hedgehogs consistently nested in proximity to some habitats (hedgerows, roads, woodlands) but avoided others (pasture fields); the use of other habitats (arable fields, amenity grassland, buildings) varied between the two sites. These data suggest: (i) that hibernation was not a period of significant mortality at either site for individuals that had attained a sufficient weight ( $>600 \mathrm{~g})$ in autumn; but that (ii) habitat composition did significantly affect the positioning of winter nests, such that different land management practices (historic and current) could influence hibernation success.

Abstract: The West-European hedgehog (Erinaceus europaeus) has declined markedly in the UK. The winter hibernation period may make hedgehogs vulnerable to anthropogenic habitat and climate changes. Therefore, we studied two contrasting populations in England to examine patterns of winter nest use, body mass changes and survival during hibernation. No between-site differences were evident in body mass prior to hibernation nor the number of winter nests used, but significant differences in overwinter mass change and survival were observed. Mass change did not, however, affect survival rates; all deaths occurred prior to or after the hibernation period, mainly from predation or vehicle collisions. Hedgehogs consistently nested in proximity to hedgerows, roads and woodlands, but avoided pasture fields; differences between sites were evident for the selection for or avoidance of arable fields, amenity grassland and buildings. Collectively, these data indicate that hibernation was not a period of significant mortality for individuals that had attained sufficient weight $(>600 \mathrm{~g})$ pre-hibernation. Conversely, habitat composition did significantly affect the positioning of winter nests, such that different land management practices (historic and current) might potentially influence hibernation success. The limitations of this study and suggestions for future research are discussed.

Keywords: Erinaceus europaeus; farmland; habitat fragmentation; hedgerow; hibernacula; hibernation; mammal; nest 


\section{Introduction}

Agricultural intensification and climate alteration are two anthropogenic processes that have profound impacts on natural ecological systems [1-7]. The effects arise from a wide range of underlying causal factors including: habitat destruction, fragmentation and degradation [8,9]; the introduction of livestock, diseases and non-native biological control agents [10-14]; the management of wildlife where they conflict with human interests [15-18]; the application of chemical biocides [19]; and changes in the phenology of key biological events $[20,21]$. Collectively, these factors have led to the decline, extirpation and extinction of large numbers of species [22-27], but also increases in the abundance and geographic range of others (e.g., [28,29]).

One group of species that might be expected to be particularly affected by agricultural practices and changing climatic conditions are hibernators [30-33]. Hibernation has typically evolved to enable species to survive periods of prolonged food shortages by dramatically reducing levels of energy expenditure $[34,35]$. One consequence of this is that hibernating species tend to have slower reproductive rates [36], potentially increasing their long-term vulnerability to human activities.

The West-European hedgehog (Erinaceus europaeus, hereafter 'hedgehog') is a medium-sized $(<1.2 \mathrm{~kg})$ insectivorous mammal found from the Iberian Peninsula and Italy northwards into Scandinavia [37]. In Britain, hedgehogs were historically found throughout a broad range of agricultural landscapes [38-41], but rural populations have declined markedly in recent decades [42-44]. Consequently, hedgehogs are now increasingly found within areas of human habitation in this country [45-47] and elsewhere

mboxciteB48-animals-891721,B49-animals-891721. Associated with this decline has been a substantial reduction in the availability [50] and quality [51-53] of hedgerows, an important habitat for foraging [54], dispersal [55] and refuge [56], and a substantive increase in the numbers of badgers (Meles meles) $[57,58]$, an intra-guild predator [59].

During hibernation, hedgehogs face specific challenges. First, they need to accumulate sufficient fat reserves to survive for a period of many months; in Britain, hedgehogs typically hibernate from October/November to March/April [37], although the exact timing is dependent upon a combination of both temperature and food availability [60]. Second, they need to find enough appropriate building material(s) to construct a hibernaculum that will maintain the environment within the nest at an appropriate temperature; nests are preferentially constructed from the leaves of broadleaved trees [61]. Third, the habitat must be sufficiently diverse that it offers a range of nesting locations in close proximity to one another so that an individual can relocate safely if necessary. In addition, by nesting at ground level, hedgehogs are susceptible to a range of other factors such as flooding, trampling by livestock, and disturbance by e.g., land managers, walkers and domestic dogs (Canis familiaris). Finally, changes in temperature patterns throughout winter may cause hedgehogs to rouse from hibernation when natural food availability is limited.

Hibernation success is, therefore, dependent on several factors, all of which may be negatively affected by agricultural intensification and/or climate change. For example: hot dry summers, soil compaction from heavy machinery and the application of pesticides and molluscicides may all reduce food availability prior to hibernation and, therefore, limit the ability of animals to acquire sufficient fat reserves to successfully complete hibernation; habitat loss and degradation may limit the number of suitable sites for hibernacula, meaning that hedgehogs may be forced to use alternative locations/habitats where preferred nesting materials are not available or where the risk of disturbance is greater; and warmer, wetter and/or more variable winters may cause animals to rouse more often and move between nests more frequently thereby depleting fat reserves and increasing susceptibility to some forms of mortality. Ultimately, such effects would be evident as: reductions in body mass before, and increased mass loss during, hibernation; an increase in the number of winter nests used and their placement in the environment; and an increase in over-winter mortality rates. These parameters would be expected to vary between areas undergoing different types of land management practice, and potentially between sexes (e.g., females may enter hibernation in poorer condition because of the 
energetic burden of rearing offspring, whilst males may finish hibernating earlier so that they can put on weight before the mating season).

Given the wide range of ways in which human activities could affect this phase, hibernation could represent a key critical period in the dynamics of hedgehog populations [62,63]. Despite its potential importance, little research has been conducted on the hibernation behaviour of hedgehogs in Britain in the last 40 years $[37,64]$. Therefore, in this study, we radio-tracked hedgehogs at one arable-dominated and one pasture-dominated site in England over the hibernation period to quantify differences in: (i) the number of winter nest sites used; (ii) patterns of habitat selection for nests; (iii) over-winter survival rates; and (iv) over-winter changes in body mass.

\section{Materials and Methods}

Data were collected from: (1) the Brackenhurst Campus (332 ha) of Nottingham Trent University, Nottinghamshire, UK (National Grid reference: SK695523); and (2) Hartpury University and College campus (339 ha), Gloucestershire, UK (National Grid reference: SO785237). Both sites were mixed commercial farms alongside a university campus, managed under the Entry level Environmental Stewardship Scheme [65]. Brackenhurst is dominated by arable fields $(68.7 \%)$, with pasture fields, amenity grassland and woodland covering $24.4 \%, 1.9 \%$ and $2.7 \%$ of total land area, respectively. In contrast, Hartpury is dominated by pasture (34.8\%) and amenity grassland (16.8\%), with higher woodland $(8.0 \%)$ and lower arable $(30.8 \%)$ coverage than at Brackenhurst. Hedgerow length at each site is $27.1 \mathrm{~km}$ (Brackenhurst) and $16.9 \mathrm{~km}$ (Hartpury). Badgers were present at both locations: based on the numbers of setts at each site, and the frequency with which they have been photographed on motion activated trail cameras, badger density was considered comparable between the two locations. Hedgehog densities estimated in 2017 using two different methods (random encounter model based on data from trail cameras; spatial capture-recapture based on the capture history of animals along standardized transect routes) were 5.6-9.4 km-2 at Brackenhurst and $4.3-12.5 \mathrm{~km}^{-2}$ at Hartpury [66].

Fieldwork was conducted from August 2015-May 2016 and August 2016-May 2017, inclusive. Hedgehogs were captured by hand at night under licence from Natural England (ref: 20130866-0-0-0-3) using a 1-million candlepower spotlight to systematically search arable fields, pasture fields and areas of amenity grassland. Sites were surveyed at least twice per week during August and September. Once captured, animals were sexed, given a visual health check and weighed using digital scales (Salter 1035 platform scales, Salter, UK). Healthy animals weighing $\geq 600 \mathrm{~g}$ were fitted with a VHF radio transmitter (10 g: $<2 \%$ of body mass; Biotrack Ltd., Wareham, UK) glued to a region of clipped dorsal spines. All animals, regardless of body mass, were marked with coloured heat shrink tubing attached to 10 dorsal spines in a unique location; tubing was attached using a portable soldering iron. The capture location was recorded with a handheld GPS unit (Garmin GPS 60, Garmin, UK). Animals were released at the point of capture, typically within $15 \mathrm{~min}$.

\subsection{Nesting Behaviour}

Determining the onset of hibernation for each individual using radio-tracking is difficult. Previous authors have tended to use either a criterion based on the number of successive days a single nest was used, although these have been variable (e.g., seven days [67], one month [68]), or based upon a defined time period [64]. In this study, the latter approach was used as it was not possible to definitively identify the onset of hibernation based upon patterns of nest use alone (see Results) and because it was plausible that hibernating animals may have moved nests following e.g., disturbance by human activities.

Consequently, radio-tracking data were divided into three phases in line with the time periods defined by Yarnell et al. [64]: August-October (pre-hibernation); November-March (hibernation period); and April (post-hibernation). In the pre-hibernation phase, animals were located one night each week to record body mass and check transmitter attachment, and once per week during the day to determine the position of nests. In the hibernation phase, animals were located two-three 
times each week to determine the position of nests: searches were a minimum of two days apart. Radio-tracking was conducted using a Sika radio-tracking receiver and handheld, three element Yagi antenna (Biotrack).

The location of nests was recorded with a GPS unit and marked with a cane close to the nest for future identification. The position of nests was considered in the context of its specific location (e.g., in an animal burrow, hedgerow, next to or underneath a building) and the surrounding habitats (e.g., gardens, pasture, woodland). Where possible, nests were examined once they had been vacated to identify the dominant and secondary nesting materials. After examination, all nest material was left in position for future use, as hedgehogs have been found to return to nests or to occupy those of other individuals [69].

The number of nests used by each hedgehog was calculated for the time period 1 November-31 March inclusive. Where an individual had not been tracked before 1 November $(n=3)$ or up to 31 March $(n=3)$, one extra nest was added to the actual number recorded in line with the pattern of nest use observed for other animals. Differences in the number of nests used by males and females within and between the two sites were analysed using a Kruskal-Wallis test as the data were not normally distributed.

Patterns of habitat selection for winter nests were quantified by comparing the characteristics of observed (used) nest locations with those of randomly selected locations within the area available to hedgehogs. Data for each site were analysed separately. The available area was defined as the minimum convex polygon (MCP) encompassing all the diurnal and nocturnal locations from all hedgehogs radio-tracked during the study period at that site; this was used to incorporate areas outside each individual's home range [70], and is a more objective reflection of the area used by each hedgehog population collectively than an arbitrarily predefined study area [71]. Available nest locations were randomly sampled (10 times the number of used locations) within the MCP for each study area to create an available versus used dataset. The habitat characteristics of used and available nest locations were obtained by calculating the minimum Euclidian distances to each of the seven main land cover types (amenity grassland, arable fields, buildings and associated hard-standing (hereafter 'buildings'), hedgerows, pasture fields, roads and road verges (hereafter 'roads'), woodland) found in both areas. All GIS analyses were carried out using ArcMap 10.3.1 software [72].

Resource Selection Functions (RSFs, [73]) based on generalised linear models for each site were used to quantify habitat selection. A logistic regression for each site was fitted, with the response variable being the used (1: GPS nesting locations) and available locations (0: random location within the MCP area defined above). Collinearity among explanatory variables was assessed using the Pearson correlation coefficient. At Brackenhurst, but not Hartpury, the minimum distances to amenity grassland and buildings were highly correlated $(\mathrm{r}=0.7)$. Therefore, two different RSFs were built: Model A included amenity grassland but not buildings; Model B included buildings but not amenity grassland. Both amenity grassland and buildings were included in the Hartpury model.

Akaike's Information Criterion (AIC) [74,75] was used for model selection. Parameter values were averaged across models within two AIC units of the best fitting model [74].

\subsection{Patterns of Survival}

Survival rates were compared between sites using Kaplan-Meier analysis [76]. Sexes and years were combined because of relatively small sample sizes (Brackenhurst $n=10$; Hartpury: $n=21$ ), and because there was no apparent difference in the number of males and females that died at each site (see Results). Because animals were captured at different times, a staggered entry [77] design was used: the first animal was captured (Day 1) on 1 August. To avoid potential biases associated with the ad hoc recovery of untagged individuals, only radio-tagged individuals were included in this analysis. Differences in survival between the two sites were quantified using a log-rank test. 


\subsection{Body Mass Changes}

Differences in overwinter changes in mass were compared between sites and sexes using a series of general linear models. Mass loss was calculated using each individual's mass at capture as close to the start and end of the hibernation period as possible; on average, animals were captured 15.5 days before 1 November and 2.6 days after 31 March. Statistical models compared differences in body mass at the start of hibernation, and mass change and percentage mass change during hibernation. All models included SITE and SEX as fixed factors and included a SEX ${ }^{*}$ SITE interaction term. Linear correlation was also used to compare the number of nest sites used during hibernation with mass change over the hibernation period.

\subsection{Data Analysis}

General linear modelling and Kruskal-Wallis analyses were conducted using MINITAB version 19.1.1 and SPSS version 25, respectively. Survival analysis and RSF analyses were undertaken in R 3.3.3 [78] using lme4 and MuMIn packages [79,80]. All data were checked to ensure they conformed to the underlying assumptions of the tests used. All results are presented as mean $( \pm$ SD) unless otherwise specified. As it was not possible to e.g., re-capture all tagged animals or access all nest sites, and because some animals perished during the course of the study, sample sizes vary between analyses.

\section{Results}

Forty hedgehogs were found during nocturnal surveys: 33 were fitted with radio transmitters (Table 1). Data on nesting behaviour during the hibernation period were collected from 21 hedgehogs. In total, 448 nocturnal locations, 138 nests, and 1028 diurnal locations were recorded.

Table 1. Number of hedgehogs captured and radio-tagged at each site, the total number of nocturnal and diurnal locations recorded, and the number of nest sites identified.

\begin{tabular}{|c|c|c|c|c|c|}
\hline & \multicolumn{2}{|c|}{ Brackenhurst } & \multicolumn{2}{|c|}{ Hartpury } & \multirow{2}{*}{ Total } \\
\hline & 2015-2016 & 2016-2017 & 2015-2016 & 2016-2017 & \\
\hline No. captured \& marked & $7\left(4 \%: 30^{7}\right)$ & $3\left(2 \circ: 10^{7}\right)$ & $22\left(12 \circ: 10 \sigma^{7}\right)$ & 8 (3ㅇ: 5o') & 40 (21:19 \\
\hline No. radio-tagged & $7\left(4 \circ: 3 \sigma^{7}\right)$ & $3\left(2 \circ: 10^{7}\right)$ & $18\left(9 \circ: 9 \sigma^{7}\right)$ & $5\left(3 \circ: 20^{7}\right)$ & $33\left(18 \%: 15 \sigma^{7}\right)$ \\
\hline No. tracked during hibernation & $7\left(4 \circ: 30^{r}\right)$ & $3\left(2 \circ: 10^{7}\right)$ & $7\left(4 \circ: 30^{7}\right)$ & $4\left(2 \circ: 2 \sigma^{r}\right)$ & $21\left(12 \%: 90^{7}\right)$ \\
\hline $\begin{array}{l}\text { Total no. of nests recorded (\% accessible } \\
\text { for recording composition) }\end{array}$ & $54(59 \%)$ & $12(100 \%)$ & $50(66 \%)$ & $16(75 \%)$ & $138(65 \%)$ \\
\hline No. of nocturnal locations recorded & 103 & 74 & 210 & 61 & 448 \\
\hline No. of diurnal locations recorded & 408 & 114 & 360 & 146 & 1028 \\
\hline
\end{tabular}

\subsection{Nesting Behaviour}

The pattern of nest use was highly variable, with several animals using the same nest site for extended periods before and/or during the hibernation period (Figure 1). There was no significant difference in the number of nests used by males and females within and between the two sites (Kruskal-Wallis test: $\mathrm{H}=0.60, \mathrm{DF}=3, p=0.896$ ). Combining the data, hedgehogs used a median of five nests (mean $\pm \mathrm{SD}=5.5 \pm 2.3$ ) across the 151-day hibernation period. Thirteen animals $(62 \%)$ used at least one site for $\geq 89$ days. 


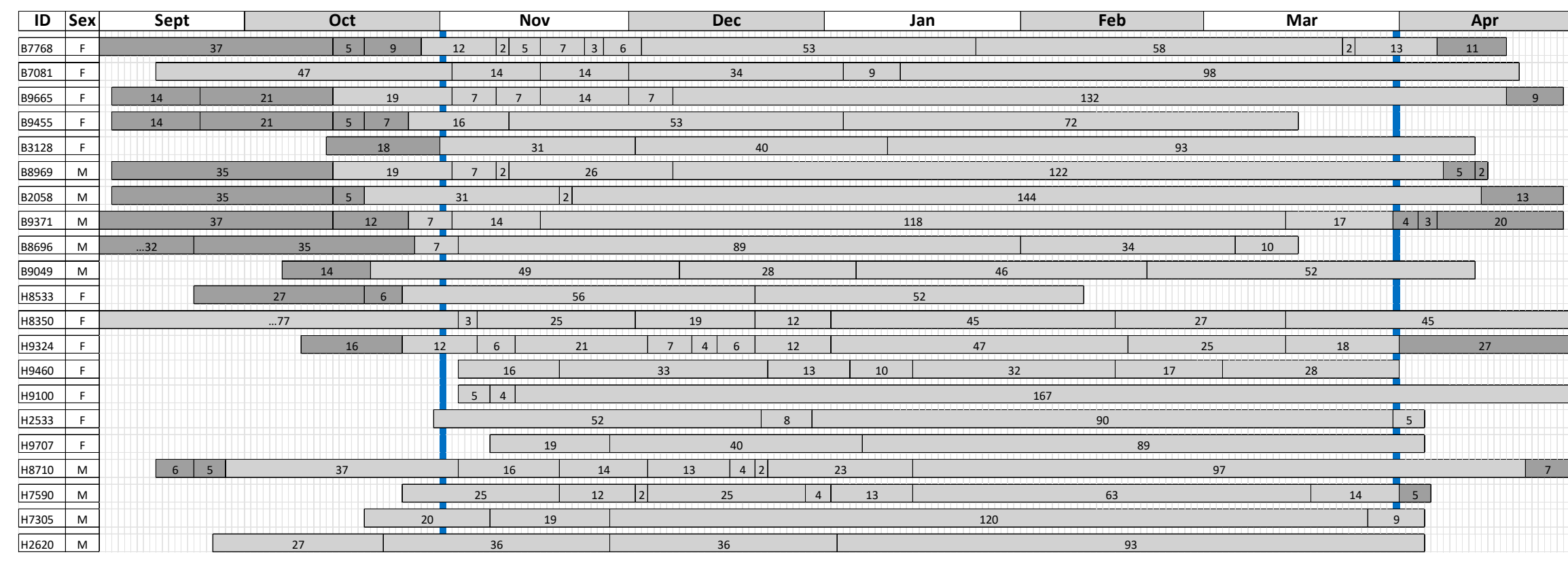

Figure 1. Pattern of occupation of winter nests by hedgehogs at Brackenhurst (ID numbers prefixed by " $B$ ") and Hartpury (ID numbers prefixed by “ $\mathrm{H}$ ”). Figures in horizontal bars indicate the number of days that each nest was estimated to be occupied based upon the sampling regime (see text for details). Vertical blue columns indicate the start (1 November) and end (31 March) of the hibernation period: dark and light shaded bars indicate nests excluded from and included in the analysis of the number of nests used over the hibernation period, respectively. 
RSF analyses indicated that woodland, roads, pasture and, to a lesser extent, hedgerows, were consistently included in the top $(\triangle \mathrm{AIC}<2)$ ranked models at both sites (Figure 2; Table 2). At both sites, hedgehogs selected nest locations closer to hedgerows, in vegetation alongside roads and in woodlands, but avoided pasture fields (Table 3). Between-site differences were evident for arable fields (neither selected nor avoided at Brackenhurst; avoided at Hartpury) and both amenity grassland and buildings (both selected for at Brackenhurst in each model where these habitats were included; neither selected nor avoided at Hartpury, or not retained in top-ranked models).

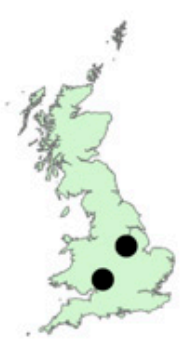

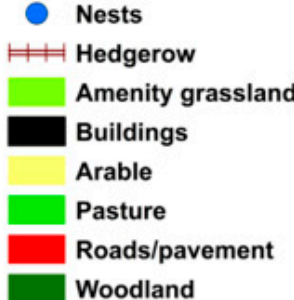

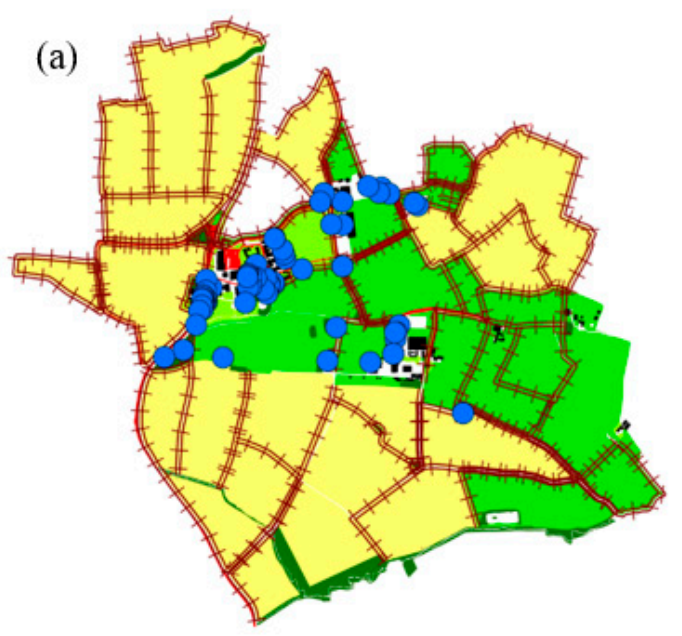

Figure 2. Position of hedgehog winter nest sites (blue dots) at (a) Brackenhurst and (b) Hartpury in relation to habitat composition. (b)

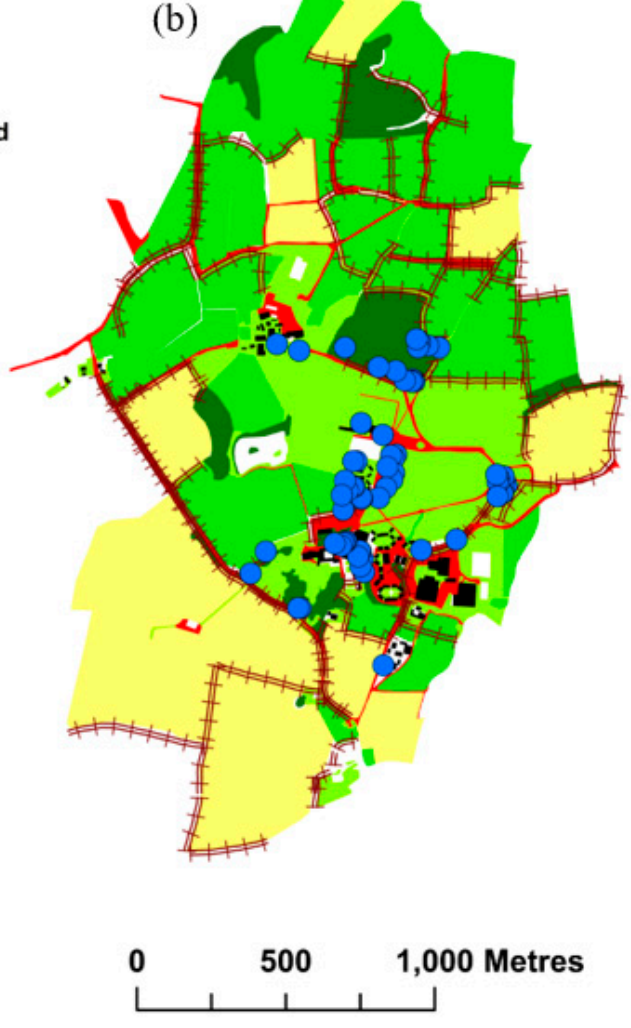


Table 2. Results of the top five a-priori models for predictors of habitat selection of hedgehog winter nests. Models are ranked based on their AIC values. Null model is also provided for comparison. Models indicated in bold were selected to build average models. Brackenhurst had two alternative maximal models, one including distance to amenity grassland (Brackenhurst Model A) and another including distance to buildings (Brackenhurst Model B). Habitats included in each of the top-ranking models are indicated by the " $\checkmark$ " symbol. Bold indicates top ranked models at each site $(\Delta \mathrm{AIC}<2)$.

\begin{tabular}{|c|c|c|c|c|c|c|c|c|c|}
\hline \multicolumn{10}{|c|}{ Brackenhurst Model A } \\
\hline \multicolumn{10}{|c|}{ Models $(\mathrm{N}=64)$} \\
\hline $\begin{array}{l}\text { Amenity } \\
\text { grassland }\end{array}$ & Buildings & Hedgerows & Pastures & Roads & Woodland & Arable & AIC & $\Delta \mathrm{AIC}$ & $\mathrm{AIC}_{\mathrm{w}}$ \\
\hline 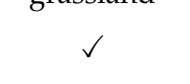 & $\begin{array}{c}\text { Not } \\
\text { included }\end{array}$ & $\checkmark$ & $\checkmark$ & $\checkmark$ & $\checkmark$ & & 357.5 & 0.00 & 0.38 \\
\hline$\checkmark$ & $\begin{array}{c}\text { Not } \\
\text { included }\end{array}$ & $\checkmark$ & $\checkmark$ & $\checkmark$ & $\checkmark$ & $\checkmark$ & 358.2 & 0.75 & 0.26 \\
\hline$\checkmark$ & $\begin{array}{c}\text { Not } \\
\text { included }\end{array}$ & & $\checkmark$ & $\checkmark$ & $\checkmark$ & $\checkmark$ & 359.4 & 1.94 & 0.14 \\
\hline$\checkmark$ & $\begin{array}{c}\text { Not } \\
\text { included }\end{array}$ & & $\checkmark$ & $\checkmark$ & $\checkmark$ & $\checkmark$ & 360.8 & 3.33 & 0.07 \\
\hline$\checkmark$ & $\begin{array}{c}\text { Not } \\
\text { included }\end{array}$ & $\checkmark$ & $\checkmark$ & & $\checkmark$ & $\checkmark$ & 362.2 & 4.67 & 0.04 \\
\hline & & & NULL & & & & 491.2 & 134.00 & $<0.01$ \\
\hline \multicolumn{10}{|c|}{ Brackenhurst Model B } \\
\hline \multicolumn{10}{|c|}{ Models $(\mathrm{N}=64)$} \\
\hline $\begin{array}{l}\text { Amenity } \\
\text { grassland }\end{array}$ & Buildings & Hedgerows & Pastures & Roads & Woodland & Arable & AIC & $\triangle \mathrm{AIC}$ & $\mathrm{AIC}_{\mathrm{w}}$ \\
\hline Not included & $\checkmark$ & $\checkmark$ & $\checkmark$ & $\checkmark$ & $\checkmark$ & & 350.2 & 0.00 & 0.41 \\
\hline Not included & $\checkmark$ & $\checkmark$ & $\checkmark$ & $\checkmark$ & $\checkmark$ & $\checkmark$ & 351.1 & 0.90 & 0.26 \\
\hline Not included & $\checkmark$ & & $\checkmark$ & $\checkmark$ & $\checkmark$ & & 352.1 & 1.89 & 0.16 \\
\hline Not included & $\checkmark$ & & $\checkmark$ & $\checkmark$ & $\checkmark$ & $\checkmark$ & 352.6 & 3.44 & 0.07 \\
\hline Not included & $\checkmark$ & $\checkmark$ & $\checkmark$ & & $\checkmark$ & $\checkmark$ & 354.3 & 4.09 & 0.05 \\
\hline & & & NULL & & & & 491.2 & 141.00 & $<0.01$ \\
\hline \multicolumn{10}{|c|}{ Hartpury } \\
\hline \multicolumn{10}{|c|}{ Models $(\mathrm{N}=128)$} \\
\hline $\begin{array}{l}\text { Amenity } \\
\text { grassland }\end{array}$ & Buildings & Hedgerows & Pastures & Roads & Woodland & Arable & AIC & $\triangle \mathrm{AIC}$ & $\mathrm{AIC}_{\mathrm{w}}$ \\
\hline & & $\checkmark$ & $\checkmark$ & $\checkmark$ & $\checkmark$ & $\checkmark$ & 395.6 & 0.00 & 0.49 \\
\hline & $\checkmark$ & $\checkmark$ & $\checkmark$ & $\checkmark$ & $\checkmark$ & $\checkmark$ & 397.4 & 1.80 & 0.20 \\
\hline$\checkmark$ & & $\checkmark$ & $\checkmark$ & $\checkmark$ & $\checkmark$ & $\checkmark$ & 397.6 & 2.04 & 0.18 \\
\hline$\checkmark$ & $\checkmark$ & $\checkmark$ & $\checkmark$ & $\checkmark$ & $\checkmark$ & $\checkmark$ & 399.4 & 3.84 & 0.07 \\
\hline & & $\checkmark$ & $\checkmark$ & & $\checkmark$ & $\checkmark$ & 401.2 & 5.61 & 0.03 \\
\hline & & & NULL & & & & 464.4 & 68.8 & $<0.01$ \\
\hline
\end{tabular}


Table 3. Model averaged values of the best a-priori models $(\triangle \mathrm{AIC}<2)$ investigating habitat selection for winter nest sites. SE $=$ standard error. Brackenhurst had two alternative models, one including distance to amenity grassland but excluding buildings (Brackenhurst Model A) and another including distance to buildings but excluding amenity grassland (Brackenhurst Model B). Negative values indicate a higher probability of nesting closer to that specific habitat.

\begin{tabular}{|c|c|c|c|c|c|c|c|c|c|c|c|c|}
\hline \multirow{2}{*}{ Variable } & \multicolumn{4}{|c|}{ Brackenhurst Model A (3 Best a-priori Models) } & \multicolumn{4}{|c|}{ Brackenhurst Model B (3 Best $a$-priori Models) } & \multicolumn{4}{|c|}{ Hartpury (2 Best $a$-priori Models) } \\
\hline & Estimate & SE & $\mathbf{z}$ & $p$-Value & Estimate & SE & $\mathbf{z}$ & $p$-Value & Estimate & SE & $\mathbf{z}$ & $p$-Value \\
\hline (Intercept) & -0.281 & 0.439 & 0.640 & 0.522 & -0.113 & 0.432 & 0.261 & 0.794 & -2.514 & 0.515 & 4.879 & $<0.001$ \\
\hline Hedgerows & -0.013 & 0.006 & 2.000 & $<0.05$ & -0.013 & 0.006 & 2.000 & $<0.05$ & -0.008 & 0.003 & 3.204 & $<0.01$ \\
\hline Pasture & 0.017 & 0.006 & 2.942 & $<0.01$ & 0.017 & 0.006 & 2.877 & $<0.01$ & 0.010 & 0.003 & 3.748 & $<0.001$ \\
\hline Roads & -0.012 & 0.005 & 2.544 & $<0.05$ & -0.010 & 0.004 & 2.443 & $<0.05$ & -0.016 & 0.006 & 2.590 & $<0.01$ \\
\hline Woodland & -0.020 & 0.003 & 5.919 & $<0.001$ & -0.020 & 0.003 & 5.607 & $<0.001$ & -0.013 & 0.003 & 3.774 & $<0.001$ \\
\hline Arable & 0.002 & 0.002 & 1.127 & 0.260 & 0.002 & 0.002 & 1.062 & 0.288 & 0.005 & 0.001 & 3.436 & $<0.001$ \\
\hline Buildings & \multicolumn{4}{|c|}{ Not included } & -0.01 & 0.003 & 3.412 & $<0.001$ & 0.001 & 0.001 & 0.488 & 0.626 \\
\hline Amenity grassland & -0.008 & 0.003 & 2.527 & $<0.05$ & \multicolumn{4}{|c|}{ Not included } & \multicolumn{4}{|c|}{ Not included } \\
\hline
\end{tabular}


At both sites, winter nests were primarily constructed from broad leaves (major component in $45 \%$ and 51\% of nests, respectively: Supplementary Table S1). Major differences in the relative proportion of nests containing different materials were, however, evident. For example, litter and/or plastic waste was present in 20 nests (24\%) at Hartpury, although never as the dominant material, but was never recorded at Brackenhurst.

\subsection{Patterns of Survival}

Nine animals died during the study, with no apparent sex difference in mortality risk (Brackenhurst: $1 \sigma^{x}$; Hartpury: 4 o:4 $\left.4 \sigma^{\top}\right)$. The overall survival rate was significantly lower at Hartpury (Log-rank test: $X^{2}{ }_{1}=9.46, p=0.002$ ). All deaths occurred before or after the hibernation period (Figure 3 ). The most common single known cause of death was predation by badgers ( 3 of 9 deaths; see Supplementary Table S2).

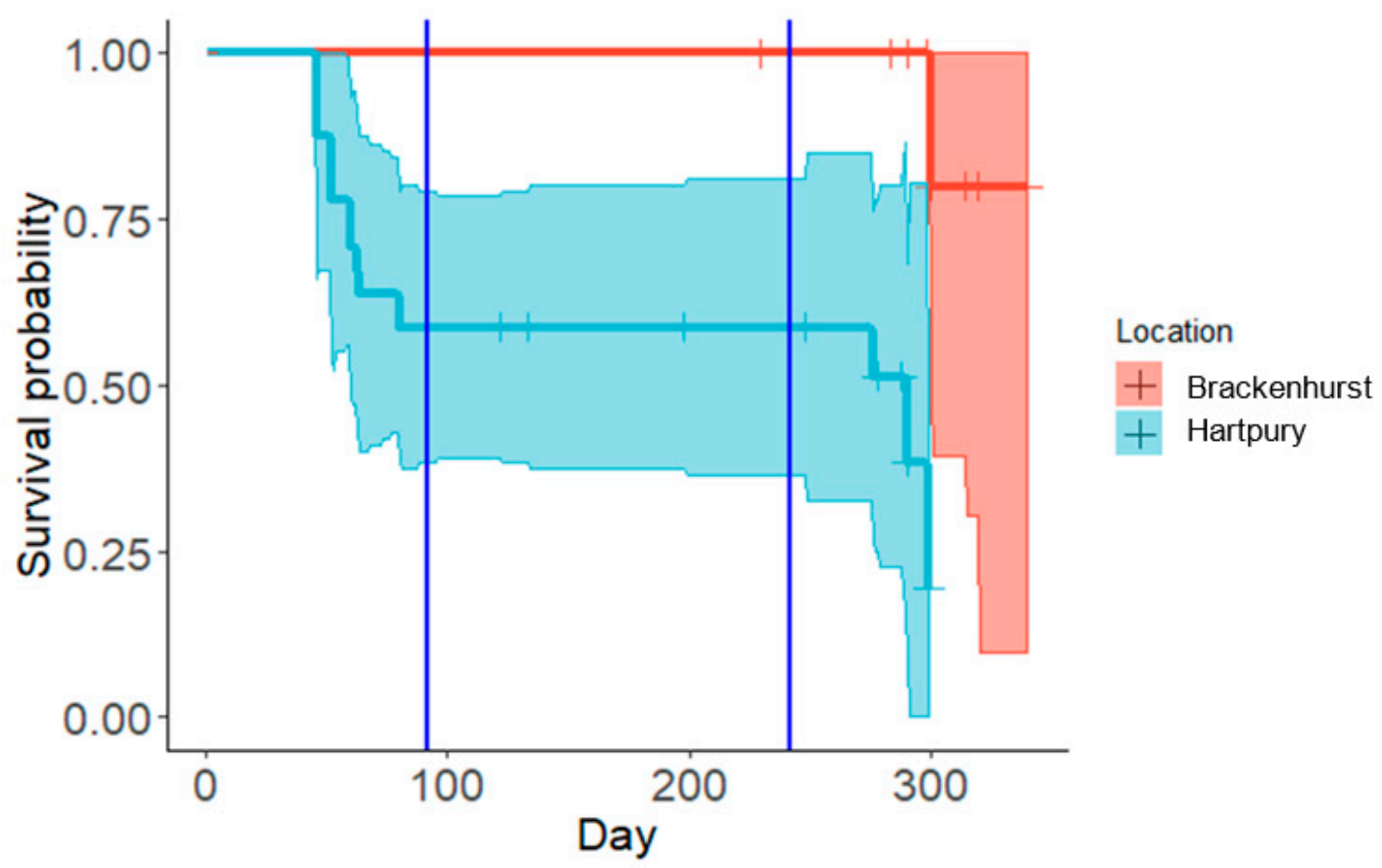

Figure 3. Kaplan-Meir survival functions for hedgehogs at Brackenhurst $(n=10)$ versus Hartpury $(\mathrm{n}=21)$. Data from sexes and years $(2015-2016$ and 2016-2017) combined. Vertical blue lines indicate the start (1 November) and end (31 March) of the hibernation period.

\subsection{Body Mass Changes}

Data on body mass changes across the study were available for 21 individuals. There was no significant SITE $\left(F_{1,17}=3.75, p=0.069\right), \operatorname{SEX}\left(F_{1,17}=0.78, p=0.389\right)$ or $\operatorname{SITE}{ }^{*} \operatorname{SEX}\left(F_{1,17}=3.75\right.$, $p=0.943$ ) differences in mean body mass at the start of the hibernation period (Supplementary Table S3); collectively, hedgehogs weighed $869 \pm 133 \mathrm{~g}$ (females: $843 \pm 144 \mathrm{~g}$; males: $898 \pm 120 \mathrm{~g}$ ).

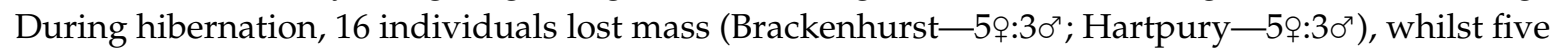

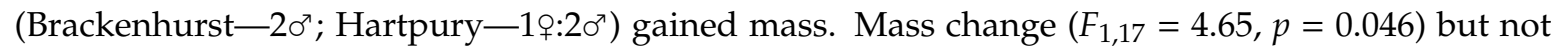
percentage mass change $\left(F_{1,17}=4.22, p=0.056\right)$ differed significantly between the sexes at each site, although the latter was close to significance. At Brackenhurst, females lost $242 \pm 150 \mathrm{~g}$ on average whilst males gained a small amount of weight ( $4 \pm 89 \mathrm{~g}$; Figure 4); male and female hedgehogs at Hartpury lost $117 \pm 121 \mathrm{~g}$ and $110 \pm 141 \mathrm{~g}$, respectively. These figures are equivalent to average percentage mass changes of $-25 \%,+1 \%,-14 \%$ and $-15 \%$, respectively (Supplementary Figure S1). 


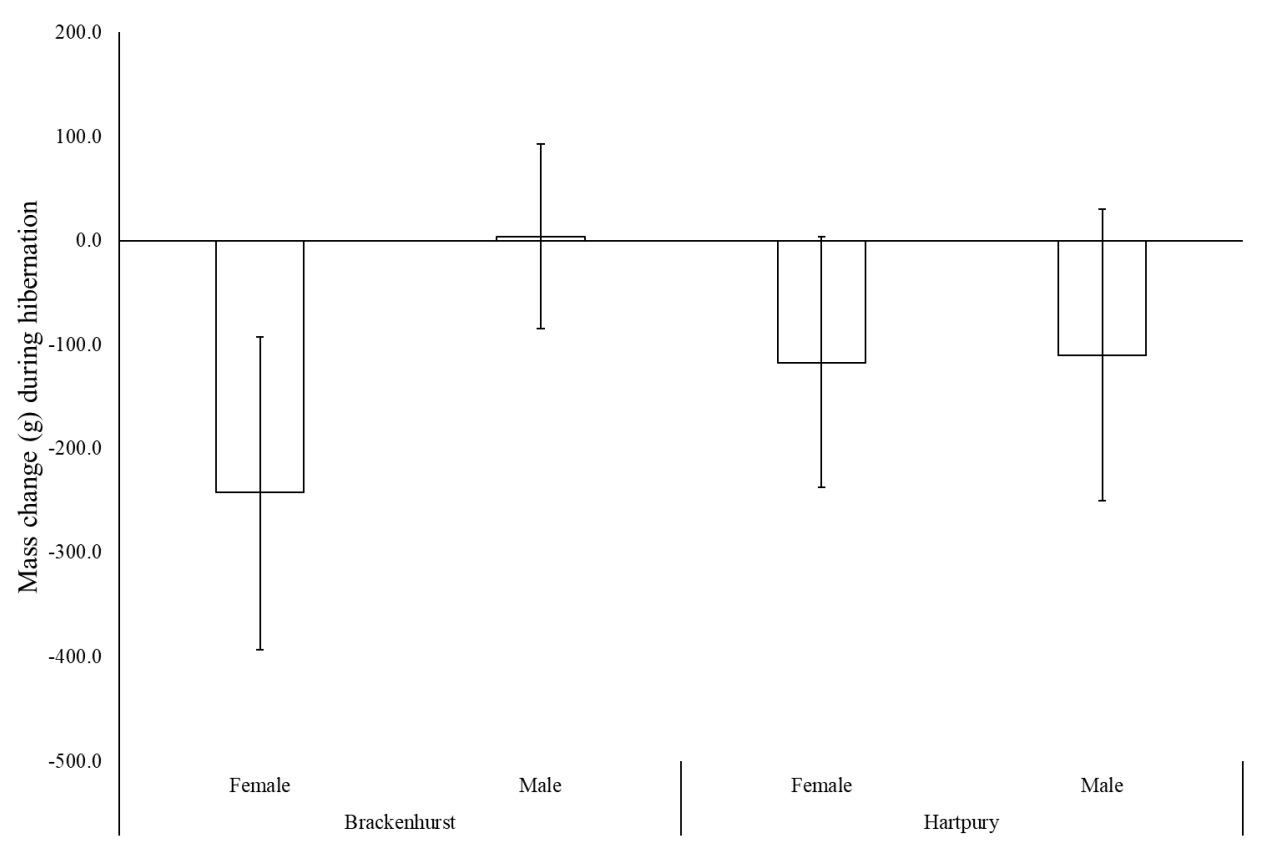

Figure 4. Mean $( \pm \mathrm{SD})$ mass change during the hibernation period (1 November-31 March) in relation to site and sex (Brackenhurst: $n=50: 5 \sigma^{7}$; Hartpury: $n=60: 5 \sigma^{7}$ ).

There was a negative correlation between the number of nest sites used and the loss in body mass, although this was not significant $(\mathrm{r}=-0.409, \mathrm{n}=21, p=0.066$; Figure 5). However, this was dependent on the extreme loss exhibited by a single female at Brackenhurst (432 g); excluding this female, the relationship is significant $(\mathrm{r}=-0.561, \mathrm{n}=20, p=0.010)$.

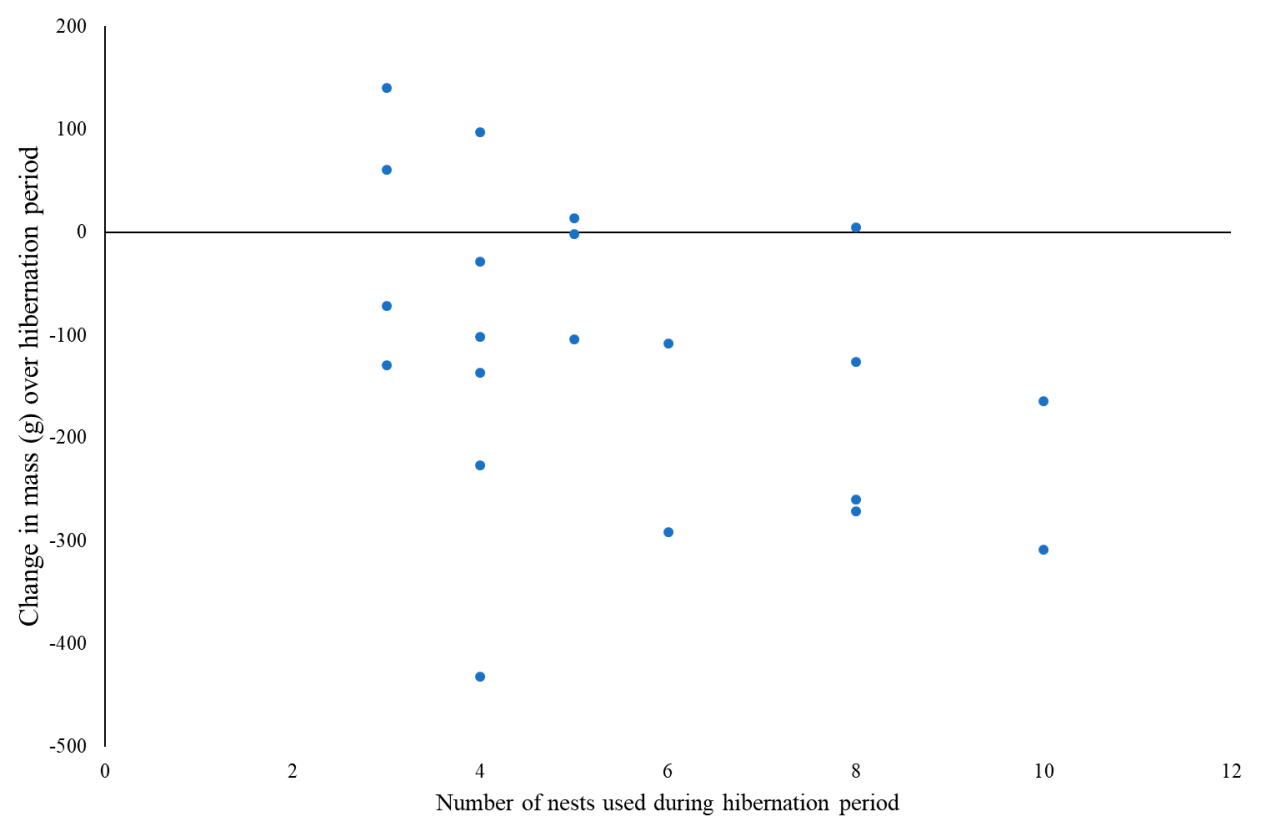

Figure 5. Relationship between number of nests used during the hibernation period (1 November -31 March) and the corresponding change in mass $(\mathrm{g})$ over the hibernation period $(\mathrm{n}=21)$.

\section{Discussion}

In this study, we investigated four factors associated with the winter hibernation period of hedgehogs that could potentially be affected by agricultural land-use and climate change: (i) patterns of body mass change; (ii) frequency of winter nest use; (iii) habitat selection for winter nest sites; and (iv) 
over-winter survival. Between the two sites studied, one dominated by arable crop production and the other by pasture and amenity grasslands, there were no apparent differences in body mass at the start of hibernation, the number of nest sites used during winter, and the selection for and avoidance of many, but not all, major habitats as nesting locations. In contrast, there were significant differences between the study sites with respect to sex-specific changes in body mass, the use of hedgerows and buildings for nesting, and patterns of survival.

\subsection{Change in Body Mass}

Estimated body mass of radio-tagged animals at the outset of the hibernation period was not significantly different between Brackenhurst and Hartpury, with animals weighing, on average $869 \pm 133 \mathrm{~g}$. This is likely due, in part, to the fact that we only radio-tagged individuals $\geq 600 \mathrm{~g}$ in accordance with guidance relating to the release of rehabilitated hedgehogs by the major wildlife welfare organisation in the UK [81]. This reliance on radio-tagged individuals to ensure that individuals captured before hibernation could be re-captured afterwards does, however, preclude obtaining data on animals below this threshold weight.

Acknowledging this caveat, the general pattern of mass loss observed (mean of 100-240 g within most site-sex divisions, equivalent to a mean of $14-25 \%$ of pre-hibernation mass) is within the range recorded in previous studies (Table 4). However, there was a substantial difference in sex-specific patterns of mass change at the two sites. At Hartpury, both males and females lost approximately the same amount of weight (Figure 4). Conversely, females at Brackenhurst lost markedly more weight than any other division, whereas males, on average, gained a small amount of weight. In fact, five $(23.8 \%)$ animals across both sites gained weight across the hibernation period. This could indicate that individuals may have been able to access sufficient food resources during the winter period to offset the fat reserves used during hibernation, or that some animals may have already stopped hibernating and resumed typical foraging activity before they were recaptured in March/April. Although we are not able to discriminate between these possibilities, it is clear that the magnitude of these average changes are within the survivable range documented for this species. 
Table 4. Summary of body mass changes recorded in previous studies of the West-European hedgehog over the winter hibernation period.

\begin{tabular}{|c|c|c|c|c|c|c|}
\hline Country & Habitat & Years Studied & Sample Size\& Composition & Mass Loss Recordedover Winter & $\begin{array}{l}\text { Minimum Weightto } \\
\text { SurviveHibernation }\end{array}$ & Reference \\
\hline England & Urban parkland & 1963-1968 & 105 & $25 \%$ & $\begin{array}{l}\text { Recommends } 450 \mathrm{~g} \text { ( } 550 \mathrm{~g} \text { in } \\
\text { more northern areas) }\end{array}$ & [63] \\
\hline Denmark & Rural & 2001-2002 & $10\left(5 \circ: 50^{7}\right) ;(3 \mathrm{~A}: 7 \mathrm{~J})$ & $\begin{array}{l}30.2 \pm 7.1 \%(\mathrm{~A}) \\
22.1 \pm 10.1 \%(\mathrm{~J})\end{array}$ & $513 \mathrm{~g}$ & [82] \\
\hline Ireland & Rural & 2008-2009 & 8 (7A:1J) & $\begin{array}{c}301 \pm 3.9 \mathrm{~g} \text { (\%) (range: } 15-38 \%) \\
108 \pm 2.6 \mathrm{~g}\left(\sigma^{7}\right)(\text { range: } 3-6 \%)\end{array}$ & $475 \mathrm{~g}$ in Nov & [67] \\
\hline Denmark & Suburban & 2014-2015 & $8(8 \mathrm{~J})$ & $16 \pm 2.9 \%(\mathrm{~J})$ & - & [83] \\
\hline England & Various & 2010-2014 & 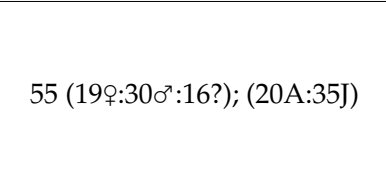 & 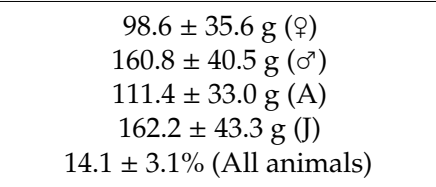 & $\begin{array}{l}\text { Recommends }>600 \mathrm{~g} \text { for } \\
\text { release, but one individual } \\
\text { weighing } 391 \mathrm{~g} \text { survived } \\
\text { release and hibernation }\end{array}$ & [64] \\
\hline England & Various & 2015-2017 & $21\left(110: 10 \sigma^{r}\right)$ & $\begin{array}{l}\text { Site 1: } 240 \pm 150 \mathrm{~g}(25 \pm 13 \%) \text { (o) } \\
\text { Site 1: }-4 \pm 89 \mathrm{~g}(1 \pm 9 \%)\left(\sigma^{7}\right) \\
\text { Site 2: } 117 \pm 121 \mathrm{~g}(14 \pm 16 \%) \text { ( ) } \\
\text { Site 2: } 110 \pm 141 \mathrm{~g}(15 \pm 19 \%)\left(0^{\top}\right)\end{array}$ & - & Present study \\
\hline
\end{tabular}


Mass loss was also negatively correlated with the number of nests used in the winter period (Figure 5), although not significantly $(p=0.066)$. The lack of significance may, in part, be attributable to the relatively small sample size $(n=21)$, the highly variable changes in mass recorded, and the presence of one female that lost $>400 \mathrm{~g}$ ( $40 \%$ of her body mass). Although this is among one of the largest percentage mass losses ever recorded (Table 4) and was $>100 \mathrm{~g}$ more than any other individual in this study, this individual survived to spring. As rousing from hibernation is energetically expensive [84], hedgehogs would be expected to avoid doing so unnecessarily to avoid depleting their fat reserves. Rousing is likely to occur in response to environmental fluctuations, including both rises or falls in temperature [60], but in anthropogenic landscapes, it may also occur in response to human disturbance. To date, however, there are very few data on the extent to which disturbances affect hedgehog hibernation, either by causing them to move nests or rouse but remain in the same nest [85], and what impacts these may have on energy consumption and mortality risk.

\subsection{Nesting Behaviour}

Hedgehogs used a median of 5 (mean: 5.5) nests during the 151-day hibernation period. This is markedly higher than that observed in other studies (Table 5). Drawing direct comparisons between the number of nests used in such studies is, however, problematic because of the methodological differences used to define the onset and duration of hibernation, coupled with latitudinal differences in weather and/or temperature which extend or shorten the overall length of the hibernation period. It is worth noting, however, that the mean number of nests used by the animals in this study was more than twice that ( 1.74 nests per 100 days $=2.6$ nests over 151 days) recorded in the most recent study of hedgehogs in England and which utilized the same dates for defining the hibernation period [64]. 
Table 5. Summary of over-winter nesting behaviour in previous studies of the West-European hedgehog. Studies are listed in chronological order.

\begin{tabular}{|c|c|c|c|c|c|c|}
\hline Country & Habitat & Years Studied & $\begin{array}{l}\text { Sample Size\& } \\
\text { Composition }^{1}\end{array}$ & $\begin{array}{c}\text { Duration of } \\
\text { Hibernation(Days) }\end{array}$ & Number of Nests Used & Reference \\
\hline England & Urban park & $1963-1967$ & 167 nests & Not recorded & $\begin{array}{l}\text { Mean occupation time }=1.4 \\
\text { months (range } 0-6 \text { months) }\end{array}$ & {$[61]$} \\
\hline Denmark & Rural & 2001-2002 & 10 (3A:7J) & $\begin{array}{l}197.7 \pm 2.2(\mathrm{~A}) \\
178.8 \pm 13.1(\mathrm{~J})\end{array}$ & 2.2 (range: $1-4$ ) & [82] \\
\hline Ireland & Rural & 2008-2010 & 8 (7A:1J) & $\begin{array}{c}167.3 \pm 10.5(\text { ( ) } \\
148.6 \pm 10.2\left(\sigma^{7}\right) \\
155.4 \pm 9.0(\mathrm{~A}) \\
157(\mathrm{~J})\end{array}$ & $\begin{array}{c}2.0 \pm 0.6(\text { (ㅇ) } \\
3.2 \pm 0.6\left(\mathrm{\sigma}^{7}\right) \\
2.4 \pm 0.7(\mathrm{~A}) \\
5.0(\mathrm{~J})\end{array}$ & [67] \\
\hline Finland & Urban & 2004-2006 & $11(11 \mathrm{~A})\left(5 \circ: 60^{7}\right)$ & $\begin{array}{l}223 \pm 2.5 \text { (ㅇ) } \\
224 \pm 4.8\left(\sigma^{7}\right)\end{array}$ & $\begin{array}{l}1.0(\text { ( ) }) \\
1.0\left(0^{7}\right)\end{array}$ & [68] \\
\hline Denmark & Urban & $2014-2015$ & $8(8 \mathrm{~J})$ & $138.0 \pm 5.6(\mathrm{~J})$ & $1.8 \pm 0.14(\mathrm{~J})$ & [83] \\
\hline England & Various & 2010-2014 & 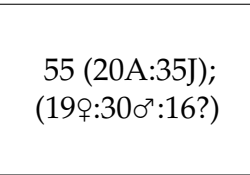 & Not recorded & $\begin{array}{c}2.2 \pm 0.5(\text { () } \\
\\
1.7 \pm 0.4\left(\sigma^{7}\right)^{2} \\
1.8 \pm 0.4(\mathrm{~A})^{2} \\
2.6 \pm 0.6(\mathrm{~J})^{2}\end{array}$ & {$[64]$} \\
\hline England & Arable & 2015-2017 & 21A $\left(12 \%: 90^{7}\right)$ & Not recorded & $\begin{array}{l}5.8 \pm 2.6(\text { (ᄋ) } \\
5.0 \pm 1.9\left(\sigma^{7}\right)\end{array}$ & Present study \\
\hline
\end{tabular}

${ }^{1}$ Data were recorded by the authors either in terms of the number of nests studied or the number of individuals studied: A = adult; J = juvenile; ? = unknown sex. ${ }^{2}$ The number of nests used per 100 days. 
The increased number of nests used in our study was associated with periods during November, December and/or January where several individuals used a series of nests in quick succession (Figure 1). Although some of these periods of frequent movements between nests could be interpreted as indicating that an individual had not yet started hibernating, the patterns of nest retention exhibited throughout the study as a whole were extremely variable such that it is difficult to identify clear general trends. The possible exception to this is that the majority (62\%) of animals used a single nest location for $>89$ days, with many of these used for the first time in November or December; this is markedly higher than the $21 \%$ of nests $(n=167$ ) occupied for $\geq 3$ months reported by Morris [61] in west London.

Clear patterns in nest location were evident for most, but not all, habitats. Hedgehogs consistently avoided nesting near pasture fields, whilst favouring hedgerows, woodlands and roads. In contrast, differing patterns of selection were evident for arable fields, buildings and amenity grassland. At Brackenhurst, nests were preferentially located near to amenity grassland and near buildings, although these habitats were strongly correlated with one another, whereas arable fields were neither selected nor avoided. Conversely, at Hartpury, arable fields were avoided, buildings were neither selected nor avoided and amenity grassland was not retained in the top-ranked models. These data imply that agricultural habitats were generally unsuitable for hibernation, a finding consistent with behaviour outside the hibernation period that has been attributed to a combination of reduced food availability [86] and increased risk of predation from and competition with badgers [44-49,59,87].

Hedgerows and woodland were an important habitat for nesting, a pattern that is evident in both summer and winter seasons in other studies [47,68,82,88]. Similarly, the selection for roads in this study is also most probably associated with the presence of hedgerows as borders along roads at both sites. In addition to acting as nesting sites, hedgerows are also recognised as an important refuge habitat whilst foraging where badgers are present $[47,56]$ and for orientation through fragmented landscapes [55]. As such, the general loss and degradation of hedgerows in the UK [50,89,90] is likely to have negatively affected hedgehog populations due to impacts at multiple stages in their annual cycle, although the exact mechanisms are unknown because of the relative paucity of data on rural hedgehog populations and behaviour since the 1950s [91].

Similarly, there are few data on the importance of woodlands for hedgehogs. For example, woodlands were not identified as a factor affecting patterns of occupancy in a national survey of England and Wales [44], they were the least selected habitat in a radio-tracking study in arable landscapes [47], and no hedgehogs were detected in woodland in a pilot project on the Hartpury campus investigating the efficacy of three different methods for surveying hedgehogs [92]: all these studies were, however, conducted in the summer. The preference for woodlands as sites for hibernation observed in this study, and the reliance on broad leaves as nesting material, may suggest that hedgehogs tend to avoid woodlands during the summer months but use them as sites for hibernating during the winter months. As outlined above, one possible reason for these seasonal differences is the presence of badgers, which favour woodlands and plantations as sites for their setts [93] but undergo a period of torpor in winter [94]. Consequently, hedgehogs could be avoiding woodlands during the summer when badgers are active but using them as hibernation sites in the winter when the risk from badgers is markedly lower. As such, woodlands may represent a key resource for hedgehogs but only during one phase of their annual cycle. The impact of historical changes in the coverage of different types of woodland [95,96], their management and their interaction with an increasing badger population $[57,58]$ on hedgehog populations are unknown but require investigation. For example, in their recent report, Mathews et al. [43] estimated that 37\% of the British hedgehog population was supported by broadleaved woodland.

The affinity for amenity grassland as a foraging habitat has been well documented in Britain, most notably in the context of responses to the culling of badgers as a means for managing bovine tuberculosis in cattle $[45,46,59]$. During winter these areas are likely to be associated with low levels of badger activity (due to torpor) but also possibly marginally higher average temperatures than surrounding areas due to their proximity to buildings, and provision of food either accidentally 
(discarded refuse) or deliberately (although we were not aware of anyone deliberately feeding hedgehogs on either campus). However, amenity areas on university campuses are likely to experience high levels of pedestrian activity except in particularly poor weather and over the Christmas holiday period. The presence of buildings on these two sites also enabled hedgehogs to use some unusual nest locations, including piles of building materials and underground heating tunnels.

\subsection{Over-Winter Survival}

Survival across the study period as a whole (August-April) was significantly lower at Hartpury versus Brackenhurst. However, this was not associated with differences in mortality during the hibernation period itself, but rather mortality prior to the onset of hibernation and in the period after animals had resumed foraging in spring: in fact, none of the tagged animals in this study $(n=31)$ died during the hibernation period itself (Figure 3). Consequently, mortalities were not related to body mass per se but stochastic events such as predation by badgers and road traffic accidents (although it could be argued that animals which have not yet accumulated sufficient fat reserves and/or those that leave hibernation having lost a large amount of might be expected to take greater risks when foraging). However, it must be emphasised that these survival data are based on animals that were in good physical condition (visually health-checked and $\geq 600 \mathrm{~g}$ ) prior to hibernation in accordance with welfare guidelines; this is substantially higher than the minimum threshold of 450-513 g outlined in Table 4, and which would tend to elevate survival rates.

The survival rate observed at Hartpury, when measured from August to April (approximately $65 \%)$, was lower than that recorded in Sweden $(57-96 \%$, mean $=71 \%$ ) over seven years in the 1970s [62], whereas the survival rates at both sites when measured from October to April were comparable to studies from England (83\%) Ireland (100\%), Denmark (89-90\%) and Finland (100\%) conducted between 2001 and 2017 [64,67,82,97]. Overall, this body of evidence suggests that, in general terms, the survival rate of animals that have accumulated sufficient fat reserves prior to hibernation is likely to be high, but that site-specific pressures associated with movements in autumn and spring can substantially increase mortality rates [64].

\section{Conclusions}

This study has identified key similarities and differences in four key parameters associated with the winter hibernation of hedgehogs across two sites associated with different patterns of land management. Most notably, the period of hibernation itself, when hedgehogs are generally inactive within hibernacula, is not associated with high levels of mortality. Conversely, it is the periods before and after entering hibernation that pose significant risks, predominantly from stochastic factors such as badger predation and vehicle collisions. In addition, hedgehogs at both sites consistently avoided nesting in proximity to pastoral fields during winter, but favoured locations near to hedgerows, woodlands and roads. Selection for or avoidance of arable fields, buildings, and amenity grasslands varied between the two sites.

However, this study was associated with several practical limitations. Data could only be reliably collected from radio-tagged individuals and radio-tags can only be fitted to animals weighing $\geq 600 \mathrm{~g}$ for welfare reasons. Radio-tracking is also limited in the extent to which the start and end of the hibernation period (for each individual) can be identified reliably, and the ease with which data on short-term patterns of movement between nests can be collected given that animals are inactive for many successive days. Future studies, therefore, need to consider the use of other technologies, such as GPS tracking devices [98] and animal-mounted bio-loggers [99], to overcome these constraints. In particular, such studies need to focus on: (i) quantifying patterns of survival of animals weighing $<600 \mathrm{~g}$; (ii) identifying factors associated with nest movements and whether this affects mass change during hibernation; and (iii) the role of woodlands in the annual cycle of hedgehogs in both arable and pastoral dominated landscapes. 
Supplementary Materials: The following are available online at http://www.mdpi.com/2076-2615/10/9/1449/s1, Figure S1: Mean $( \pm \mathrm{SD})(\mathrm{a})$ body mass $(\mathrm{g})$ at the start of the hibernation season, and $(\mathrm{b})$ percentage mass change during the hibernation period in relation to site and sex (Brackenhurst: $n=5$ o: $50^{7}$; Hartpury: $n=60: 50^{7}$ ), Table S1: Summary of the dominant materials used in winter nest construction at Brackenhurst and Hartpury. Data for 2015-2016 and 2016-2017 combined. Figures in parentheses are the number of nests where the material was recorded as a secondary material. Sample sizes are less than the total number of nests used by study animals as not all nests were accessible, Table S2: Cause of death $(n=9)$ from a sample of 31 individuals followed over two winter hibernation periods (2015-2016 or 2016-2017), Table S3: General linear models comparing site and sex differences in (a) body mass ( $\mathrm{g}$ ) at the start of the hibernation season, and (b) mass change and (c) percentage mass change during the hibernation period $(n=21)$.

Author Contributions: Conceptualization, R.W.Y.; methodology, R.W.Y., D.S., A.U., L.E.B.-B., L.E. and P.J.B.; validation, R.W.Y., L.E.B.-B. and P.J.B.; formal analysis, R.W.Y., L.E.B.-B., A.U., L.E. and P.J.B.; investigation, R.W.Y., D.S., A.U. and L.E.B.-B.; resources, R.W.Y., and L.B.B.; data curation, R.W.Y., L.E.B.-B., and P.J.B.; writing-original draft preparation, L.E.B.-B., P.J.B.; writing—review and editing, all authors; visualization, R.W.Y., A.U., L.E., L.E.B.-B., P.B.; supervision, R.W.Y., P.J.B.; project administration, R.WY.; funding acquisition, R.W.Y., D.S., A.U., L.E.B.-B., P.J.B. All authors have read and agreed to the published version of the manuscript.

Funding: This research was funded by the Peoples' Trust for Endangered Species and British Hedgehog Preservation Society.

Acknowledgments: The authors would like to thank the volunteers who assisted with data collection, the land owners where data collection was undertaken and Vicky Boult who assisted with some GIS mapping. Particular thanks go to our funders; People's Trust for Endangered Species and British Hedgehog Preservation Society.

Conflicts of Interest: The authors declare no conflict of interest. The funders had no role in the design of the study; in the collection, analyses, or interpretation of data; in the writing of the manuscript, or in the decision to publish the results.

\section{References}

1. Parmesan, C. Ecological and evolutionary responses to recent climate change. Annu. Rev. Ecol. Evol. Syst. 2006, 37, 637-669. [CrossRef]

2. Firbank, L.G.; Petit, S.; Smart, S.; Blain, A.; Fuller, R.J. Assessing the impacts of agricultural intensification on biodiversity: A British perspective. Philos. Trans. R. Soc. B Biol. Sci. 2008, 363, 777-787. [CrossRef]

3. Tscharntke, T.; Clough, Y.; Wanger, T.C.; Jackson, L.; Motzke, I.; Perfecto, I.; Vandermeer, J.; Whitbread, A. Global food security, biodiversity conservation and the future of agricultural intensification. Biol. Conserv. 2012, 151, 53-59. [CrossRef]

4. Tuck, S.L.; Winqvist, C.; Mota, F.; Ahnström, J.; Turnbull, L.A.; Bengtsson, J. Land-use intensity and the effects of organic farming on biodiversity: A hierarchical meta-analysis. J. Appl. Ecol. 2014, 51, 746-755. [CrossRef]

5. Veach, V.; Moilanen, A.; Di Minin, E. Threats from urban expansion, agricultural transformation and forest loss on global conservation priority areas. PLOS ONE 2017, 12, 1-14. [CrossRef] [PubMed]

6. Zabel, F.; Delzeit, R.; Schneider, J.M.; Seppelt, R.; Mauser, W.; Václavík, T. Global impacts of future cropland expansion and intensification on agricultural markets and biodiversity. Nat. Commun. 2019, 10, 1-10. [CrossRef] [PubMed]

7. Firbank, L.G.; Attwood, S.; Eory, V.; Gadanaski, Y.; Lynch, J.M.; Sonnino, R.; Takahashi, T. Grand challenges in sustainable intensification and ecosystem services. Front. Sustain. Food Syst. 2018, 2, 7. [CrossRef]

8. Ellis, E.C.; Goldewijk, K.K.; Siebert, S.; Lightman, D.; Ramankutty, N. Anthropogenic transformation of the biomes, 1700 to 2000. Glob. Ecol. Biogeogr. 2010, 19, 589-606. [CrossRef]

9. Crooks, K.R.; Burdett, C.L.; Theobald, D.M.; Rondinini, C.; Boitani, L. Global patterns of fragmentation and connectivity of mammalian carnivore habitat. Philos. Trans. R. Soc. B Biol. Sci. 2011, 366, 2642-2651. [CrossRef]

10. Robinson, T.P.; Wint, G.R.; Conchedda, G.; Van Boeckel, T.P.; Ercoli, V.; Palamara, E.; Cinardi, G.; D'Aietti, L.; Hay, S.I.; Gilbert, M. Mapping the global distribution of livestock. PLoS ONE 2014, 9. [CrossRef]

11. Wiethoelter, A.K.; Beltrán-Alcrudo, D.; Kock, R.; Mor, S.M. Global trends in infectious diseases at the wildlife-livestock interface. Proc. Natl. Acad. Sci. USA 2015, 112, 9662-9667. [CrossRef] [PubMed]

12. Gordon, I.J. Review: Livestock production increasingly influences wildlife across the globe. Animal 2018, 12, S372-S382. [CrossRef] [PubMed] 
13. Howell, H.J.; Mothes, C.C.; Clements, S.L.; Catania, S.V.; Rothermel, B.B.; Searcy, C.A. Amphibian responses to livestock use of wetlands: New empirical data and a global review. Ecol. Appl. 2019, 29, 1-15. [CrossRef] [PubMed]

14. Öllerer, K.; Varga, A.; Kirby, K.; Demeter, L.; Biró, M.; Bölöni, J.; Molnár, Z. Beyond the obvious impact of domestic livestock grazing on temperate forest vegetation-A global review. Biol. Conserv. 2019, 237, 209-219. [CrossRef]

15. Baker, P.J.; Boitani, L.; Harris, S.; Saunders, G.; White, P.C.L. Terrestrial carnivores and human food production: Impact and management. Mamm. Rev. 2008, 38, 123-166. [CrossRef]

16. Eklund, A.; López-Bao, J.V.; Tourani, M.; Chapron, G.; Frank, J. Limited evidence on the effectiveness of interventions to reduce livestock predation by large carnivores. Sci. Rep. 2017, 7, 1-9. [CrossRef] [PubMed]

17. van Eeden, L.M.; Eklund, A.; Miller, J.R.B.; López-Bao, J.V.; Chapron, G.; Cejtin, M.R.; Crowther, M.S.; Dickman, C.R.; Frank, J.; Krofel, M.; et al. Carnivore conservation needs evidence-based livestock protection. PLoS Biol. 2018, 16, 1-8. [CrossRef]

18. van Eeden, L.M.; Crowther, M.S.; Dickman, C.R.; Macdonald, D.W.; Ripple, W.J.; Ritchie, E.G.; Newsome, T.M. Managing conflict between large carnivores and livestock. Conserv. Biol. 2018, 32, 26-34. [CrossRef]

19. Garcês, A.; Pires, I.; Rodrigues, P. Teratological effects of pesticides in vertebrates: A review. J. Environ. Sci. Heal.Part. B Pestic. Food Contam. Agric. Wastes 2020, 55, 75-89. [CrossRef]

20. Brown, D.D.; Kays, R.; Wikelski, M.; Wilson, R.; Klimley, A. Observing the unwatchable through acceleration logging of animal behavior. Anim. Biotelemetry 2013, 1. [CrossRef]

21. Kharouba, H.M.; Ehrlén, J.; Gelman, A.; Bolmgren, K.; Allen, J.M.; Travers, S.E.; Wolkovich, E.M. Global shifts in the phenological synchrony of species interactions over recent decades. Proc. Natl. Acad. Sci. USA 2018, 115, 5211-5216. [CrossRef] [PubMed]

22. Butchart, S.H.M.; Walpole, M.; Collen, B.; van Strien, A.; Scharlemann, J.P.W.; Almond, R.E.A.; Baillie, J.E.M.; Bomhard, B.; Brown, C.; Bruno, J.; et al. Global Biodiversity: Indicators of recent declines. Science 2010, 1164, 1164-1169. [CrossRef] [PubMed]

23. Hoffmann, M.; Hilton-Taylor, C.; Angulo, A.; Böhm, M.; Brooks, T.M.; Butchart, S.H.M.; Carpenter, K.E.; Chanson, J.; Collen, B.; Cox, N.A.; et al. The impact of conservation on the status of the world's vertebrates. Science 2010, 330, 1503-1509. [CrossRef] [PubMed]

24. Di Marco, M.; Boitani, L.; Mallon, D.; Hoffmann, M.; Iacucci, A.; Meijaard, E.; Visconti, P.; Schipper, J.; Rondinini, C. A Retrospective evaluation of the global decline of carnivores and ungulates. Conserv. Biol. 2014, 28, 1109-1118. [CrossRef] [PubMed]

25. Maxwell, S.L.; Fuller, R.A.; Brooks, T.M.; Watson, J.E.M. Biodiversity: The ravages of guns, nets and bulldozers. Nature 2016, 536, 143-145. [CrossRef]

26. Dudley, N.; Alexander, S. Agriculture and biodiversity: A review. Biodiversity 2017, 18, 45-49. [CrossRef]

27. Stanton, R.L.; Morrissey, C.A.; Clark, R.G. Analysis of trends and agricultural drivers of farmland bird declines in North America: A review. Agric. Ecosyst. Environ. 2018, 254, 244-254. [CrossRef]

28. Clout, M.N.; Russell, J.C. The invasion ecology of mammals: A global perspective. Wildl. Res. 2007, 35, 180-184. [CrossRef]

29. Long, J.L. Introduced Mammals of the World: Their History, Distribution and Influence; CSIRO Publishing: Victoria, Australia, 2003.

30. Inouye, D.W.; Barr, B.; Armitage, K.B.; Inouye, B.D. Climate change is affecting altitudinal migrants and hibernating species. Proc. Natl. Acad. Sci. USA 2000, 97, 1630-1633. [CrossRef]

31. Lane, J.E. Evolutionary Ecology of Mammalian Hibernation Phenology. In Living in a Seasonal World; Ruf, T., Bieber, C., Arnold, W., Millesi, E., Eds.; Springer: Berlin, Germany, 2012; pp. 51-61. ISBN 9783642286780.

32. Lane, J.E.; Kruuk, L.E.B.; Charmantier, A.; Murie, J.O.; Dobson, F.S. Delayed phenology and reduced fitness associated with climate change in a wild hibernator. Nature 2012, 489, 554-557. [CrossRef]

33. Geiser, F. Hibernation. Curr. Biol. 2013, 23, 188-193. [CrossRef] [PubMed]

34. Geiser, F. Hibernation: Endotherms. eLS 2011, 1. [CrossRef]

35. Staples, J.F. Metabolic suppression in mammalian hibernation: The role of mitochondria. J. Exp. Biol. 2014, 217, 2032-2036. [CrossRef] [PubMed]

36. Turbill, C.; Bieber, C.; Ruf, T. Hibernation is associated with increased survival and the evolution of slow life histories among mammals. Proc. R. Soc. B Biol. Sci. 2011, 278, 3355-3363. [CrossRef] [PubMed] 
37. Morris, P.A.; Reeve, N.J. Hedgehog Erinaceus europaeus. In Mammals of the British Isles: Handbook; Harris, S.J., Yalden, D.W., Eds.; The Mammal Society: Southampton, UK, 2008; pp. 241-249.

38. Burton, M. The Hedgehog; Andre Deutsch: London, UK, 1969.

39. Tapper, S.S. Game Heritage: An Ecological Review from Shooting and Gamekeeping Records; Game Conservancy Ltd.: Fordingbridge, Hampshire, UK, 1992.

40. Arnold, H.R. Atlas of Mammals of Britain; HMSO: London, UK, 1993.

41. Lovegrove, R. Silent Fields: The Long Decline of a Nation's Wildlife; Oxford University Press: Oxford, UK, 2007.

42. Hof, A.R.; Bright, P.W. Quantifying the long-term decline of the West European hedgehog in England by subsampling citizen-science datasets. Eur. J. Wildl. Res. 2016, 62, 407-413. [CrossRef]

43. Mathews, F.; Kubasiewicz, L.M.; Gurnell, J.; Harrower, C.A.; McDonald, R.A.; Shore, R.F. A Review of the Population and Conservation Status of British Mammals. A report by the Mammal. Society under contract to Natural England, Natural Resources Wales and Scottish Natural Heritage; Natural England: Peterborough, UK, 2018; ISBN 9781783544943.

44. Williams, B.M.; Baker, P.J.; Thomas, E.; Wilson, G.J.; Judge, J.; Yarnell, R.W. Reduced occupancy of hedgehogs (Erinaceus europaeus) in rural England and Wales: The influence of habitat and an asymmetric intra-guild predator. Sci. Rep. 2018, 8, 12156. [CrossRef]

45. Young, R.P.; Davison, J.; Trewby, I.D.; Wilson, G.J.; Delahay, R.J.; Doncaster, C.P. Abundance of hedgehogs (Erinaceus europaeus) in relation to the density and distribution of badgers (Meles meles). J. Zool. 2006, 269, 349-356. [CrossRef]

46. Parrott, D.; Etherington, T.R.; Dendy, J. A geographically extensive survey of hedgehogs (Erinaceus europaeus) in England. Eur. J. Wildl. Res. 2014, 60, 399-403. [CrossRef]

47. Pettett, C.E.; Moorhouse, T.P.; Johnson, P.J.; Macdonald, D.W. Factors affecting hedgehog (Erinaceus europaeus) attraction to rural villages in arable landscapes. Eur. J. Wildl. Res. 2017, 63, 54. [CrossRef]

48. Hubert, P.; Julliard, R.; Biagianti, S.; Poulle, M.L. Ecological factors driving the higher hedgehog (Erinaceus europeaus) density in an urban area compared to the adjacent rural area. Landsc. Urban. Plan. 2011, 103, 34-43. [CrossRef]

49. Van de Poel, J.L.; Dekker, J.; Langevelde, F.V. Dutch hedgehogs Erinaceus europaeus are nowadays mainly found in urban areas, possibly due to the negative effects of badgers Meles meles. Wildl. Biol. 2015, 21, 51-55. [CrossRef]

50. Robinson, R.A.; Sutherland, W.J. Post-war changes in arable farming and biodiversity in Great Britain. J. Appl. Ecol. 2002, 39, 157-176. [CrossRef]

51. Carey, P.D.; Wallis, S.M.; Emmett, B.; Maskell, L.C.; Murphy, J.; Norton, L.R.; Simpson, I.C.; Smart, S.M. Countryside Survey: UK Headline Messages from 2007; Centre for Ecology \& Hydrology: Wallingford, UK, 2008.

52. Wright, J. A Natural History of the Hedgerow and Ditches, Dykes and Dry Stone Walls; Profile Books Ltd.: London, UK, 2016.

53. Dover, J.W. The Ecology of Hedgerows and Field Margins; Routledge: Abingdon, UK, 2019.

54. Hof, A.R.; Bright, P.W. The value of agri-environment schemes for macro-invertebrate feeders: Hedgehogs on arable farms in Britain. Anim. Conserv. 2010, 13, 467-473. [CrossRef]

55. Moorhouse, T.P.; Palmer, S.C.F.; Travis, J.M.J.; Macdonald, D.W. Hugging the hedges: Might agri-environment manipulations affect landscape permeability for hedgehogs? Biol. Conserv. 2014, 176, 109-116. [CrossRef]

56. Hof, A.R.; Snellenberg, J.; Bright, P.W. Food or fear? Predation risk mediates edge refuging in an insectivorous mammal. Anim. Behav. 2012, 83, 1099-1106. [CrossRef]

57. Judge, J.; Wilson, G.J.; Macarthur, R.; Delahay, R.J.; McDonald, R.A. Density and abundance of badger social groups in England and Wales in 2011-2013. Sci. Rep. 2014, 4, 3809. [CrossRef]

58. Judge, J.; Wilson, G.J.; Macarthur, R.; McDonald, R.A.; Delahay, R.J. Abundance of badgers (Meles meles) in England and Wales. Sci. Rep. 2017, 7, 276. [CrossRef]

59. Trewby, I.D.; Young, R.P.; McDonald, R.A.; Wilson, G.J.; Davison, J.; Walker, N.; Robertson, P.A.; Doncaster, C.P.; Delahay, R.J. Impacts of removing badgers on localised counts of hedgehogs. PLoS ONE 2014, 9, 2-5. [CrossRef]

60. Morris, P.A. Hedgehog; HarperCollins: London, UK, 2018.

61. Morris, P.A. Winter nests of the hedgehog. Oecologia 1973, 11, 299-313. [CrossRef]

62. Kristiansson, H. Population variables and causes of mortality in a hedgehog (Erinaceus europaeus) population in Southern Sweden. J. Zool. 1990, 220, 391-404. [CrossRef] 
63. Morris, P.A. An estimate of the minimum body weight necessary for hedgehogs (Erinaceus europaeus) to survive hibernation. J. Zool. 1984, 203, 291-294.

64. Yarnell, R.W.; Surgey, J.; Grogan, A.; Thompson, R.; Davies, K.; Kimbrough, C.; Scott, D.M. Should rehabilitated hedgehogs be released in winter? A comparison of survival, nest use and weight change in wild and rescued animals. Eur. J. Wildl. Res. 2019, 65. [CrossRef]

65. Natural England Entry Level Stewardship; Natural England: Sheffield, UK, 2013; ISBN 978-1-84754-239-7.

66. Schaus, J.; Uzal, A.; Gentle, L.K.; Baker, P.J.; Bearman-Brown, L.; Bullion, S.; Gazzard, A.; Lockwood, H.; North, A.; Reader, T.; et al. Application of the Random Encounter Model in citizen science projects to monitor animal densities. Remote Sens. Ecol. Conserv. 2020. [CrossRef]

67. Haigh, A.; O'Riordan, R.M.; Butler, F. Nesting behaviour and seasonal body mass changes in a rural Irish population of the Western hedgehog (Erinaceus europaeus). Acta Theriol. 2012, 57, 321-331. [CrossRef]

68. Rautio, A.; Valtonen, A.; Auttila, M.; Kunnasranta, M. Nesting patterns of European hedgehogs (Erinaceus europaeus) under northern conditions. Acta Theriol. 2014, 59, 173-181. [CrossRef]

69. Morris, P.A. Hedgehogs, 4th ed.; Whittet Books: Stansted, UK, 2014.

70. McClean, S.A.; Rumble, M.A.; King, R.M.; Baker, W.L. Evaluation of Resource Selection Methods with Different Definitions of Availability. J. Wildl. Manag. 1998, 62, 793. [CrossRef]

71. Uzal, A.; Walls, S.; Stillman, R.A.; Diaz, A. Sika deer distribution and habitat selection: The influence of the availability and distribution of food, cover, and threats. Eur. J. Wildl. Res. 2013, 59, 563-572. [CrossRef]

72. Environmental Systems Resource Institute. ArcGIS 2015; ESRI: Redlands, CA, USA, 2015.

73. Manly, B.F.L.; McDonald, L.; Thomas, D.L.; McDonald, T.L.; Erickson, W.P. Resource Selection by Animals: Statistical Design and Analysis for Field Studies; Springer: London, UK, 2007.

74. Burnham, K.P.; Anderson, D.R. Model. Selection and Multi-Model Inference: A Practical Information-Theoretic Approach; Springer: New York City, NY, USA, 2002.

75. Zuur, A.F.; Ieno, E.N.; Walker, N.; Saveliev, A.A.; Smith, G.M. Mixed Effects Models and Extensions in Ecology with R; Springer Science \& Business Media: London, UK, 2009.

76. Kaplan, E.L.; Meier, P. Nonparametric estimation from incomplete observations. J. Am. Stat. Assoc. 1958, 53, 457. [CrossRef]

77. Pollock, K.H.; Winterstein, S.R.; Bunck, C.M.; Curtis, P.D. Survival analysis in telemetry studies: The staggered entry design. J. Wildl. Manage. 1989, 53, 7-15. [CrossRef]

78. R Core Team. R: A Language and Environment for Statistical Computing; R Core Team R: Vienna, Austria, 2016.

79. Bates, D.; Machler, M.; Bolker, B.; Walker, S. Fitting Linear Mixed-Effects Models Using lme4. J. Stat. Softw. 2015, 67, 1-48. [CrossRef]

80. Barton, K. Package "MuMIn"; R Package Version 1(6); CRAN: 2019. Available online: https://cran.r-project. org/web/packages/MuMIn/MuMIn.pdf (accessed on 19 August 2020)

81. RSPCA. RSPCA Wildlife Rehabilitation Protocol: Hedgehogs; RSPCA: Southwater, UK, 2013.

82. Jensen, A.B. Overwintering of European hedgehogs Erinaceus europaeus in a Danish rural area. Acta Theriol. 2004, 49, 145-155. [CrossRef]

83. Rasmussen, S.L.; Berg, T.B.; Dabelsteen, T.; Jones, O.R. The ecology of suburban juvenile European hedgehogs (Erinaceus europaeus) in Denmark. Ecol. Evol. 2019, 9, 13174-13187. [CrossRef]

84. Tähti, H.; Soivio, A. Respiratory and circulatory differences between induced and spontaneous arousals in hibernating hedgehogs (Erinaceus europaeus L.). Ann. Zool. Fenn. 1977, 14, 198-203.

85. Walhovd, H. Partial arousals from hibernation in hedgehogs in outdoor hibernacula. Oecologia 1979, 153, 141-153. [CrossRef]

86. Hof, A.R.; Bright, P.W. The impact of grassy field margins on macro-invertebrate abundance in adjacent arable fields. Agric. Ecosyst. Environ. 2010, 139, 280-283. [CrossRef]

87. Pettett, C.E.; Johnson, P.J.; Moorhouse, T.P.; Hambly, C.; Speakman, J.R.; Macdonald, D.W. Daily energy expenditure in the face of predation: Hedgehog energetics in rural landscapes. J. Exp. Biol. 2017, 220, 460-468. [CrossRef]

88. Riber, A. Habitat use and behaviour of European hedgehog Erinaceus europaeus in a Danish rural area. Acta Theriol. 2006, 51, 363-371. [CrossRef]

89. Sutherland, W.J.; Armstrong-Brown, S.; Armsworth, P.R.; Brereton, T.; Brickland, J.; Campbell, C.D.; Chamberlain, D.E.; Cooke, A.I.; Dulvy, N.K.; Dusic, N.R.; et al. The identification of 100 ecological questions of high policy relevance in the UK. J. Appl. Ecol. 2006, 43, 617-627. [CrossRef] 
90. Cornulier, T.; Robinson, R.A.; Elston, D.; Lambin, X.; Sutherland, W.J.; Benton, T.G. Bayesian reconstitution of environmental change from disparate historical records: Hedgerow loss and farmland bird declines. Methods Ecol. Evol. 2011, 2, 86-94. [CrossRef]

91. Harris, S.J.; Morris, P.A.; Wray, S.; Yalden, D.W. A Review of British Mammals: Population Estimates and Conservation Status of British Mammals Other than Cetaceans; JNCC: Peterborough, UK, 1995; ISBN 1-873701-68-3.

92. Bearman-Brown, L.E.; Wilson, L.E.; Evans, L.; Baker, P.J. Comparing non-invasive surveying techniques for elusive, nocturnal mammals: A case study of the West European hedgehog (Erinaceus europaeus). J. Vertebr. Biol. in press.

93. Wilson, G.; Harris, S.J.; McLaren, G. Changes in the British Badger Population, 1988 to 1997; Kerenza J Ltd.: London, UK, 1997.

94. Roper, T.J. Badger; HarperCollins: London, UK, 2010.

95. Hopkins, J.J.; Kirby, K.J. Ecological change in British broadleaved woodland since 1947. Ibis 2007, 149, $29-40$. [CrossRef]

96. Amar, A.; Smith, K.W.; Butler, S.; Lindsell, J.A.; Hewson, C.M.; Fuller, R.J.; Charman, E.C. Recent patterns of change in vegetation structure and tree composition of British broadleaved woodland: Evidence from large-scale surveys. Forestry 2010, 83, 345-356. [CrossRef]

97. Rautio, A.; Valtonen, A.; Kunnasranta, M. The effects of sex and season on home range in European hedgehogs at the northern edge of the species range. Ann. Zool. Fenn. 2013, 50, 107-123. [CrossRef]

98. Glasby, L.; Yarnell, R.W. Evaluation of the performance and accuracy of Global Positioning System bug transmitters deployed on a small mammal. Eur. J. Wildl. Res. 2013, 59, 915-919. [CrossRef]

99. Chmura, H.E.; Glass, T.W.; Williams, C.T. Biologging physiological and ecological responses to climatic variation: New tools for the climate change era. Front. Ecol. Evol. 2018, 6. [CrossRef]

(C) 2020 by the authors. Licensee MDPI, Basel, Switzerland. This article is an open access article distributed under the terms and conditions of the Creative Commons Attribution (CC BY) license (http://creativecommons.org/licenses/by/4.0/). 